\title{
Nuclear Medicine Methods in the Assessment of Acupuncture Effects: A Short Review
}

\author{
Deise Elisabete Souza ${ }^{1,2}$, Bernardo Machado Rebello ${ }^{1,2}$, Reginaldo de Carvalho Silva \\ Filho $^{3}$, Raquel Terra Agostinho ${ }^{1,2}$, Sohaku R. C. Bastos ${ }^{2}$ and Mario Bernardo-Filho ${ }^{1,4}$ \\ ${ }^{1}$ Universidade do Estado do Rio de Janeiro; Instituto de Biologia Roberto Alcantara Gomes; Departamento de \\ Biofísica e Biometria; Laboratório de Radiofarmácia Experimental; Av. 28 de Setembro, 87; 20551-030; \\ deise_desouza@yahoo.com.br; Rio de Janeiro - RJ - Brasil. ${ }^{2}$ Academia Brasileira de Arte e Ciência Oriental; Rio \\ de Janeiro - RJ - Brasil. ${ }^{3}$ Escola Brasileira de Medicina Chinesa; Centro Avançado de Pesquisas em Ciências \\ Orientais; São Paulo - SP - Brasil. ${ }^{4}$ Instituto Nacional de Câncer; Centro de Pesquisa Básica; Rio de Janeiro - RJ - \\ Brasil
}

\begin{abstract}
The mechanisms of acupuncture are poorly understood. In consequence, numerous investigators have conducted clinical trials to test the efficacy of acupuncture in various conditions. We have used PubMed database system to evaluate the number of publications in acupuncture and nuclear medicine procedures in the period from 1964 to 2007, using the keywords: "nuclear medicine and acupuncture", "SPECT and acupuncture", "PET and acupuncture", "scintigraphy and acupuncture", "radionuclide and acupuncture", "radiopharmaceutical and acupuncture", "radioisotope and acupuncture" and " ${ }^{99 m}$ Tc and acupuncture". Some papers published in English language were selected and a short review is presented The analysis of the number of publications shows that when a method is well accepted by the scientific community, as the methods used in nuclear medicine, the interest in the development of research increases. Moreover, important findings are presented when the nuclear medicine image is used to evaluate the effect of the acupuncture.
\end{abstract}

Key words: Acupuncture, nuclear medicine, Traditional Chinese Medicine

\section{INTRODUCTION}

In nuclear medicine, radionuclides such as technetium-99m $\left({ }^{99 \mathrm{~m}} \mathrm{Tc}\right)$ are widely used to label molecular and cellular structures (radiopharmaceuticals). The radiopharmaceuticals are utilized to study blood flow, metabolism, morphology of an organ or system (Chandra, 1998) and to evaluate the drug formulation and drug delivery systems (Perkins and Frier, 1999). Scintigraphic images using single photon emission computerized tomography (SPECT) and/or positron emission tomography (PET) which demonstrate the physiological processes of a tissue, allow measurement of physiologic processes as well as alterations related to various diseases (Hladik III et al., 1987; Early and Sodee, 1995; Saha, 2004). The availability of sophisticated imaging methods such as SPECT and PET, as well as in vitro experimental assays (Senna-Fernandes et al., 2006; Souza et al., 2007), have prompted their use to study techniques used in the Traditional Chinese Medicine (TCM), as

* Author for correspondence 
acupuncture (Newberg et al., 2005; Campbell, 2006).

Recent interest in complementary and alternative medicine has promoted research on various procedures for healing and health care (Kawakita et al., 2006). The TCM is a system that deals with the physiology and pathology, as well as diagnosis, prevention and treatment of disease. The TCM considers the body, the man and the nature world as an inseparable whole. Using the method of synthetic analysis, TCM, on the macroscopic point of view, studies dynamic intrinsic relationships of the body and the relationship between interior and exterior environment and then makes clear the basic physiology to serve medical practice (Zhixian, 2003).

The general theory of TCM is based on the premise that there are patterns of energy flow (qi) through the body that are essential for health and several techniques, as acupuncture, phytotherapy, moxabustion and qigong use this approach. Disruptions of this flow are believed to be responsible for several diseases. Acupuncture describes a family of procedures involving the stimulation of anatomical locations on the skin by thin, solid and metallic needles, which are manipulated manually or by electrical stimulation (Ramsay and Greenman, 1998; Sugai et al., 2004; Takahashi, 2006).

In TCM, internal organs (zang-fu organs) are divided into three groups: (a) five zang organs, (b) six $f u$ organs, and (c) extraordinary organs. The five zang organs include the heart (including pericardium), lung, spleen, liver and kidneys; their functions are stated mainly to produce and store essence: $q i$, blood and body fluid. The six $f u$ organs refer to the gallbladder, stomach, large intestine, small intestine, urinary bladder and sanjiao (tri-heater or triple energizer); their functions are anecdotally cited to receive and digest food, to absorb nutritive substances, to transmit and excrete waste. The extraordinary organs are regarded as extra fu-organs, including the brain, marrow, bone, vessels, gallbladder and uterus. However, their functions are similar to those of the zang organs (Chen, 1998; Yamamura, 2001).

The mechanisms of acupuncture are still poorly understood. In consequence, several investigators have conducted clinical trials to test the efficacy of acupuncture for various conditions (Moffet, 2006). Various methods, as the used in nuclear medicine and radiopharmacy with clinical or basic approaches, have been utilized to try to obtain scientific evidences about the techniques used in TCM (Yin et al., 2003; Schlunzen et al., 2007).

The interest of the scientific community in a specific subject can be evaluated by the analysis of the number and quality of published papers in journals that are indexed in database system, as in PubMed. Therefore, the aim of this study was to use the PubMed database system to evaluate the number of publications with the techniques of acupuncture, and to compare these findings with the publications in nuclear medicine. Moreover, short review and a discussion of some published papers in English involving acupuncture and techniques with radiopharmaceuticals found in PubMed are also presented.

\section{MATERIALS AND METHODS}

The searches were performed in PubMed (http://www.ncbi.nlm.nih.gov/PubMed) in the period 1964 to 2007 using the keywords: (i) "nuclear medicine and acupuncture", (ii) "SPECT and acupuncture", (iii) "PET and acupuncture", (iv) "scintigraphy and acupuncture", (v) "radionuclide and acupuncture", (vi) "radiopharmaceutical and acupuncture", (vii) "radioisotope and acupuncture" and (viii) " $" 99 \mathrm{~m} \mathrm{Tc}$ and acupuncture" in the link (http://w w w . n c b i . $\mathrm{n} 1 \mathrm{~m}$. $\mathrm{n} \mathrm{i} \mathrm{h}$. g o v: $80 / \mathrm{e} \mathrm{n} \mathrm{t} \mathrm{r}$ e /query.fcgi? $\mathrm{CMD}=$ searchandDB=PubMed). The data were obtained in July $4^{\text {th }} 2007$. The number of publications, in each year, was determined in acupuncture, nuclear medicine, SPECT, PET, scintigraphy, radionuclide, radiopharmaceutical, radioisotope and ${ }^{99 \mathrm{~m}} \mathrm{Tc}$. The total number of citations in each subject in the studied period was also determined. We have selected some papers published in English to further discussion

\section{RESULTS AND DISCUSSION}

In general, a small number of publications related with the studied subjects was found. The PubMed search, using the keywords (i) "nuclear medicine and acupuncture" yielded 30 publications; (ii) "SPECT and acupuncture" yielded 9 articles, (iii) "radionuclide and acupuncture" were 50 articles, (iv) "scintigraphy and acupuncture" were 33 articles, (v) "PET and acupuncture" were 19 
articles, (vi) "radiopharmaceutical and acupuncture" were 0 articles, (vii) "radioisotope and acupuncture" were 16 articles and (viii) " ${ }^{c 99 \mathrm{~m}} \mathrm{Tc}$ and acupuncture" were 11 articles.

Numerous reports on the miracle success of various surgical operations with acupuncture needling surprised clinicians and basic researchers throughout the world, and the analgesic effect of acupuncture needling became the initial target of investigation (Kawakita et al., 2006).

After reviewing some recent studies involving acupuncture and nuclear medicine in humans, they were analyzed according to their intervention, method of the nuclear medicine used, and the diagnostic or treated characteristic (table 1). Recent (from 2001) articles published in English were included in this short review.

Moreover, some studies involving acupuncture and nuclear medicine in animals were also analyzed according to their intervention, nuclear medicine procedure, and the diagnostic or treated characteristic (table 2).

Table 1 - Some recent studies involving acupuncture and nuclear medicine in humans.

\begin{tabular}{|c|c|c|c|}
\hline Study & Intervention & $\begin{array}{l}\text { Nuclear medicine } \\
\text { method }\end{array}$ & $\begin{array}{l}\text { Diagnostic or treated } \\
\text { characteristic }\end{array}$ \\
\hline $\begin{array}{l}\text { Schlunzen et al., } \\
2007\end{array}$ & $\begin{array}{l}\text { Stimulation of acupoint } \mathrm{Heg} u \\
\text { (LI4) }\end{array}$ & PET & $\begin{array}{l}\text { Cerebral blood flow in healthy } \\
\text { humans }\end{array}$ \\
\hline Wong et al., 2006 & Body acupuncture & PET & $\begin{array}{l}\text { Brain glucose metabolism in } \\
\text { cerebral palsy }\end{array}$ \\
\hline Ha-Kawa et al., 2006 & Body acupuncture & SPECT & Cerebral blood flow in dystonia \\
\hline Newberg et al., 2005 & Acupuncture analgesia & SPECT & $\begin{array}{l}\text { Cerebral blood flow in chronic } \\
\text { pain }\end{array}$ \\
\hline Yin et al., 2003 & $\begin{array}{l}\text { Stimulation of acupoint } \\
\text { Zusanli (ST36) }\end{array}$ & PET & $\begin{array}{l}\text { Brain function in healthy } \\
\text { humans }\end{array}$ \\
\hline Lee et al., 2003 & $\begin{array}{l}\text { Stimulation of acupoints LI4, } \\
\text { Shousanli (LI10), Quchi } \\
\text { (LI11), Jianyu (LI15), Jugu } \\
\text { (LI16) and Waiguan (TE5) }\end{array}$ & SPECT & Cerebral blood flow in stroke \\
\hline Hsieh et al., 2001 & Stimulation of acupoint LI4 & PET & Analgesic effect \\
\hline
\end{tabular}

Table 2 - Some recent studies involving acupuncture and nuclear medicine in animals.

\begin{tabular}{llll}
\hline Study & \multicolumn{1}{c}{ Intervention } & \multicolumn{1}{c}{$\begin{array}{c}\text { Nuclear medicine } \\
\text { procedure }\end{array}$} & $\begin{array}{c}\text { Diagnostic or treated } \\
\text { characteristic }\end{array}$ \\
\hline Souza et al.,2007 & $\begin{array}{l}\text { Stimulation of acupoint } \\
\text { Sanyinjiao (SP6) in } \\
\text { Wistar rats }\end{array}$ & $\begin{array}{l}\text { Bioavailability of } \\
\text { radiopharmaceutical } \\
\text { sodium pertechnetate }\end{array}$ & $\begin{array}{l}\text { Uptake of the } \\
\text { radiopharmaceutical in } \\
\text { organs }\end{array}$ \\
$\begin{array}{l}\text { Senna-Fernandes et al., } \\
2006\end{array}$ & $\begin{array}{l}\text { Stimulation of } \\
\text { acupoint ST36 in Wistar } \\
\text { rats }\end{array}$ & $\begin{array}{l}\text { Bioavailability of } \\
\text { radiopharmaceutical } \\
\text { sodium pertechnetate }\end{array}$ & $\begin{array}{l}\text { Uptake of the } \\
\text { radiopharmaceutical in } \\
\text { organs }\end{array}$ \\
Choi et al., 2002 & $\begin{array}{l}\text { Electroacupuncture } \\
\text { stimulation of acupoint } \\
\text { ST36 in Sprague-Dawley } \\
\text { rats }\end{array}$ & $\begin{array}{l}\text { Radiolabeled of cells with } \\
{ }^{51} \mathrm{Cr}\end{array}$ & $\begin{array}{l}\text { Splenic natural killer cell } \\
\text { activity }\end{array}$ \\
& & & \\
\hline
\end{tabular}

For several years, a number of authors have attempted to scientifically investigate the field of acupuncture, specifically the anatomic relevance of acupuncture points and their connections, known as "meridians" (De Vernejoul et al., 1992). Acupuncture has been used in the treatment of 
pain for over 2300 years in China (Zhixian, 2003) and is firmly established as a method of pain control.

The development of experimental models to help understanding the possible mechanism of action of the stimulation of acupoints is worthwhile. In nuclear medicine, a radiopharmaceutical presents a normal bioavailability that might be altered due to diseases and this fact is important to define the diagnosis of a disorder. Protocols that evaluate the bioavailability of radiopharmaceuticals have permitted to investigate the influence of certain synthetic drugs (Gomes et al., 2002; Jankovic and Djokic, 2005), natural products (Moreno et al., 2004), physical exercises (Llaurado et al., 1981; Ollenberger et al., 1998) and stimulation of acupuncture points (Senna-Fernandes et al., 2006; Souza et al., 2007).

Occasionally, unconventional forms of treatment can cause unexpected results when modern diagnostic procedures are applied, as occurred with the patient in the study of Kuno and Cerqueira (1995). A man with back pain was referred for a bone scintigraphy, and the images of the skull showed increased uptake in several regions of the skull, upon questioning, the patient stated that he had received acupuncture treatment for his back pain several times in the same regions as the increased uptake. They suggested that acupuncture can cause enhanced bone metabolism demonstrated by increased activity on bone scintigraphy. These findings are important due to an inadequate interpretation of the nuclear medicine image could lead to misdiagnosis or the necessity to repeat the examination increasing the radiation dose to the patient and staff (Hladik III et al., 1987; Bernardo-Filho et al., 2005).

Newberg et al. (2005) investigated the cerebral blood flow changes associated with the analgesic effect of acupuncture in patients with chronic pain. The baseline scintigraphy of the pain patients showed significant asymmetric uptake in the thalami compared to controls. This asymmetry reversed or normalized after the acupuncture therapy. The results from these cases show that hexamethyl propyleneamine oxime (HMPAO)SPECT is capable of detecting changes in cerebral blood flow associated with pain and that acupuncture analgesia is associated with changes in the activity of the frontal lobes, brain stem, and thalami.

The use of models to study the interactions between acupuncture stimulation and bioavailability of radiopharmaceuticals labelled with ${ }^{99 \mathrm{~m}} \mathrm{Tc}$ may help to understand the potential actions of acupuncture points in different organs and tissues. Senna-Fernandes et al. (2006) have shown that the stimulation of the acupuncture point Zusanli (ST36) has increased the uptake of the radiopharmaceutical ${ }^{99 \mathrm{~m}} \mathrm{Tc} \quad-$ sodium pertechnetate $\left(\mathrm{Na}^{99 \mathrm{~m}} \mathrm{TcO}_{4}\right)$ in some organs (heart, spleen, pancreas, stomach, brain and testis) from Wistar rats, and Souza et al. (2007) showed that stimulating the Sanyinjiao (SP6) point, the bioavailability of $\mathrm{Na}^{99 \mathrm{~m}} \mathrm{TcO}_{4}$ was significantly altered in the small intestine.

The PET imaging of brain function in the study of Yin et al. (2003) showed increase in the glycometabolism in the hypothalamus, head of the caudate nucleus, temporal lobe, the sinistral cerebellum, postcentral gyrus, and brain stem while the acupoint ST36 was being punctured. Moreover, the study of Schlunzen et al. (2007) showed that the manual acupuncture stimulation of LI4 point demonstrated a significant decrease in regional cerebral blood flow in the right medial frontal gyrus and in the left putamen measured with PET.

A repercussion of scientific work depends on the quality and the reputation of the journal where the paper is published. These journals are indexed in databases, as PubMed, and, in general, are available, as abstract or full paper to the scientific community (Moffet, 2006) and are also used as a tool to study the interest in some subjects (SantosFilho et al., 2003). The analysis of the results (table 1 and table 2) shows that when a method is well accepted by the scientific community, as the methods used in nuclear medicine, the interest in the development of research increases. Moreover, important findings are presented in this work when the nuclear medicine image is used to evaluate the effect of the acupuncture.

\section{CONCLUSIONS}

Understanding the physiologic basis of acupuncture may be critical to producing reproducible results. However, the effects of acupuncture must be mediated through physiology and investigators should be able to suggest some possible mechanisms. Proposing and testing ideas about the underlying mechanisms of acupuncture could eventually lead to a real understanding about how acupuncture does work. Furthermore, the 
publications found in the PubMed have aided to evaluate the scientific interest in acupuncture and in nuclear medicine.

\section{ACKNOWLEDGEMENTS}

This study was supported by Fundação de Amparo à Pesquisa do Estado do Rio de Janeiro (FAPERJ), Universidade do Estado do Rio de Janeiro (UERJ), Conselho Nacional de Pesquisa e Desenvolvimento (CNPq).

\section{RESUMO}

Os mecanismos de ação da acupuntura ainda não são completamente esclarecidos. Em conseqüência, diversos pesquisadores têm conduzido testes clínicos para verificar a eficiência da acupuntura em condições diversas. Nós utilizamos o sistema de base de dados PubMed para avaliar o número de publicações em acupuntura e procedimentos em medicina nuclear no período de 1964 até 2007, usando as palavraschaves: "medicina nuclear e acupuntura", "SPECT e acupuntura", "PET e acupuntura", "cintilografia e acupuntura", "radionuclídeo e acupuntura", "radiofármaco e acupuntura", "radioisótopo e acupuntura" e "99m Tc e acupuntura". Alguns artigos publicados em inglês foram selecionados e uma pequena revisão é apresentada. A análise do número de publicações mostra que quando um método é bem aceito pela comunidade científica, como os métodos utilizados em medicina nuclear, o interesse em desenvolver novos estudos aumenta. Além disso, importantes achados são apresentados quando a imagem da medicina nuclear é utilizada para avaliar o efeito da acupuntura.

\section{REFERENCES}

Bernardo-Filho, M., Santos-Filho, S. D., Moura, E. G., Maiworm, A. I., Orlando, M. M. C., Penas, M. E., Cardoso, V. N., Bernardo, L. C. and Brito, L. C. (2005), Drug interaction with radiopharmaceuticals: a review. Braz Arch Biol Techn., 48, 13-27.

Campbell, A. (2006), Point specificity of acupuncture in the light of recent clinical and imaging studies. Acupunct Med., 24, 118-122.
Chandra, R. (1998), .Nuclear Medicine Physics the Basics. Williams and Wilkins, New York.

Chen, X. N. (1998), Chinese Acupuncture and Moxibustion. Revised Edition. Foreign Languages Press, Beijing.

Choi, G. S., Oha, S. D., Han, J.B., Bae, H. S., Cho, Y. W., Yun, Y. S., Lee, W. K., Ahn, H. J. and Min, B. I. (2002), Modulation of natural killer cell activity affected by electroacupuncture through lateral hypothalamic area in rats. Neurosci Lett., 329, 1-4.

De Vernejoul, P., Albarede, P. and Darras, J. C. (1992), Nuclear medicine and acupuncture message transmission. J Nucl Med., 33, 409-412.

Early, P. J. and Sodee, D. B. (1995), Principles and Practice of Nuclear Medicine. Mosby-Year Book, Toronto.

Gomes, M. L., Mattos, D. M. M., Freitas, R. S., Diré, G. F., Lima, E. A. C., Souza, S.M.S. and BernardoFilho, M. (2002), Evaluation of the effect of mitomycin-C on the bioavaliability of technetium99m-labeled sodium pyrophosphate in mice. Cell Mol Biol., 48, 757-759.

Ha-Kawa, S. K., Yoshida, T., Yague, T., Tani, M., Suzuki, T. and Sawada, S. (2006), Acupunctureinduced cerebral blood flow responses in dystonia. Ann Nucl Med., 20, 83-87.

Hladik III, W. B., Saha, G. B. and Sudy, K. T. (1987), Essentials of Nuclear Medicine Sciences. Williams and Wilkins, Sydney.

Hsieh J. C,, Tu, C. H., Chen, F. P., Chen, M.C., Yeh, T. C., Cheng, H. C., Wu, Y. T., Liu, R. S. and Ho, L. T. (2001), Activation of the hypothalamus characterizes the acupuncture stimulation at the analgesic point in human: a positron emission tomography study. Neurosci Lett., 307, 105-108.

Jankovic, D. L. J. and Djokic, D. D. J. (2005), Alteration of the organ uptake of the $(99 \mathrm{~m}) \mathrm{Tc}-$ radiopharmaceuticals, (99m)Tc-DPD, (99m)TcDMSA, (99m)Tc-tin colloid and (99m)Tc-MAA, induced by the applied cytotoxic drugs methotrexate sodium and cyclophosphamide. Nucl Med Commun., 26, 415-419.

Kawakita, K., Shinbara, H., Imai, K., Fukuda, F., Yano, T. and Kuriyama, K. (2006), How do acupuncture and moxibustion act? Focusing on the Progress in Japanese Acupuncture Research. J Pharmacol Sci., 100, 443-459.

Kuno, R. C. and Cerqueira, M. D. (1995), Enhanced bone metabolism induced by acupuncture. $\mathrm{J} \mathrm{NucI}$ Med., 36, 2246-2247.

Lee, J. D., Chon, J. S., Jeong, H. K., Kim, H. J., Yun, M., Kim, D. Y., Kim, D. I., Park, C. I. and Yoo, H. S. (2003), The cerebrovascular response to traditional acupuncture after stroke. Neuroradiology., 45, 780784 . 
Llaurado, J. G., Smith, G. A. and Madden, J. A. (1981), Effects of exercise on kinetics and distribution of K43 and Tl-201 in isolated myocardium: concise communication. J Nucl Med., 22, 441-446.

Moffet, H. H. (2006), How might acupuncture work? A systematic review of physiologic rationales from clinical trials. BMC Complement Altern Med.., 6, 2532.

Moreno, S. R. F., Carvalho, J. J., Nascimento, A. L. R., Freitas, R. S., Diré, G. F., Lima, E. A., Lima-Filho, G. L., Rocha, L. K. and Bernardo-Filho, M. (2004), Bioavailability of sodium pertechnetate and light microscopy of organs isolated from the rats: study of the effects of a Ginkgo biloba extract. Pakistan $J$ Nutr., 3, 64-67.

Newberg, A. B., Lariccia, P. J., Lee, B. Y., Farrar, J. T., Lee, L. and Alavi, A. (2005), Cerebral blood flow effects of pain and acupuncture: a preliminary singlephoton emission computed tomography imaging study. J Neuroimaging., 15, 43-49.

Ollenberger, G. P., Matte, G., Wilkinson, A. A. and West, N. H. (1998), Relative distribution of blood flow in rats during surface and submerged swimming. Comp Biochem Phys., 119, 271-277.

Perkins, A. and Frier, M. (1999), Nuclear Medicine Pharmaceutical Research. Taylor and Francis, London.

Ramsay, D. J. and Greenman, P. E. (1998), The NIH Consensus Development Panel on Acupuncture. Acupuncture-NIH Consensus Conference. JAMA., 280, 1518-1524.

Saha, G. B. (2004), Fundamentals of Nuclear Pharmacy. 5th ed. Springer Verlag, New York.

Santos-Filho, S., Bastos, R. C. S., Pereira, F. A. O., Senna-Fernandes, V., França, D., Guilhon, S. and Bernardo-Filho, M. (2003), An evaluation of scientific papers about acupuncture. $J$ Aust Traditional-Medicine Society., 9, 1-3.

Schlunzen, L., Vafaee, M. S. and Cold, G. E. (2007), Acupuncture of LI-4 in anesthetized healthy humans decreases cerebral blood flow in the putamen measured with positron emission tomography. Anesth Analg., 104, 308-311.

Senna-Fernandes, V., França, D., Moreno, S. F., Santos-Filho, S., Rogers, P. A., Bernardo-Filho, M. and Guimarães, M. A. (2006), The effect of "Zusanli" (ST. 36) acupuncture on the bioavailability of sodium pertechnetate in Wistar rats. Acupuncture Electrother Res., 31, 33-44.

Souza, D. E., Senna-Fernandes, V., Carvalho Brito, L. C, Souza, R. S. S., França, D., Manoel, C. V, Almeida, M. C. and Bernardo-Filho, M. (2007), Acupuncture stimulation at Sanyinjiao: effect on the sodium pertechnetate bioavailability in rats. Am J Chinese Med., in press.
Sugai, G. C. M., Freire, A. O., Tabosa, A., Yamamura, Y., Tufik, S. and Mello, L. E. A. M. (2004), Serotonin involvement in the electroacupuncture and moxibustion induced gastric emptying in rats. Physiol Behav., 82, 855-861.

Takahashi, T. (2006), Acupuncture for functional gastrointestinal disorders. J Gastroenterol., 41, 408417.

Wong, V. C., Sun, J. G. and Yeung, D. W. (2006), Pilot study of positron emission tomography (PET) brain glucose metabolism to assess the efficacy of tongue and body acupuncture in cerebral palsy. $J$ Child Neurol., 21, 456-462.

Yamamura, Y. (2001), Acupuntura Tradicional - A arte de inserir. 2nd ed. Roca, São Paulo.

Yin, L., Jin, X., Qiao, W., Sun, J., Shi, X., Tian, J., Yin, D., Yao, S., Shao, M., Zeng, H., Shan, B., Tang, Y. and Zhu, K. (2003), PET imaging of brain function while puncturing the acupoint ST36. Chin Med J (Engl)., 116, 1836-1839.

Zhixian, L. (2003), Basics Theories of Traditional Chinese Medicine, ed. Academy Press. Beijing University of Traditional Chinese Medicine, China, pp. 09.
Received: July 19, 2007; Revised: August 08, 2007; Accepted: September 04, 2007. 